\title{
Glial Cell Line-Derived Neurotrophic Factor is a Survival Factor for Isolectin B4-Positive, but not Vanilloid Receptor 1-Positive, Neurons in the Mouse
}

\author{
Melissa Zwick, ${ }^{1}$ Brian M. Davis, ${ }^{4}$ C. Jeffrey Woodbury, ${ }^{3}$ John N. Burkett, ${ }^{1}$ H. Richard Koerber, ${ }^{3}$ \\ James F. Simpson, ${ }^{2}$ and Kathryn M. Albers ${ }^{4}$ \\ Departments of ${ }^{1}$ Anatomy and Neurobiology and ${ }^{2}$ Pathology, University of Kentucky School of Medicine, Lexington, \\ Kentucky 40536, and Departments of ${ }^{3}$ Neurobiology and ${ }^{4}$ Medicine, University of Pittsburgh School of Medicine, \\ Pittsburgh, Pennsylvania 15261
}

\begin{abstract}
Most, if not all, nociceptor sensory neurons are dependent on nerve growth factor (NGF) during early embryonic development. A large subpopulation of these sensory neurons loses NGF dependency between embryonic day 16 and postnatal day 14 and become responsive to glial cell line-derived growth factor (GDNF), a member of the transforming growth factor $\beta$ (TGF- $\beta$ ) family. To examine the survival and phenotypic effects of GDNF on sensory neurons in vivo, we generated transgenic mice that overexpress GDNF in the skin. GDNF-overexpresser mice had increased numbers of small unmyelinated sensory neurons that express the tyrosine kinase receptor Ret and bind the plant isolectin B4 (IB4). Surprisingly, in wild-type and trans-
\end{abstract}

Sensory nervous system development is dependent on the production of neurotrophic factors by targets of innervation such as the skin or muscle (Thoenen et al., 1987; Oppenheim, 1991). Best studied are the neurotrophins [nerve growth factor (NGF), neurotrophin-3, neurotrophin-4, and brain-derived neurotrophic factor], which support specific sensory populations during development (Snider, 1994). The transforming growth factor $\beta$ (TGF- $\beta$ ) family member, glial cell line-derived growth factor (GDNF) (Lin et al., 1993) is also expressed in the developing and adult skin (Trupp et al., 1995; Fundin et al., 1999), suggesting that, similar to neurotrophins, GDNF functions as a targetderived survival factor for cutaneous neurons. In support of this notion, GDNF promotes the in vitro survival of embryonic sensory neurons, particularly ones that bind the lectin B4 (Molliver et al., 1997). In addition, postnatal (P0) mice that lack GDNF have a $23 \%$ loss of dorsal root ganglion (DRG) neurons, further supporting a role for GDNF in neuron survival (Moore et al., 1996).

That GDNF supports isolectin B4 (IB4)-binding sensory neurons placed new emphasis on the role of the IB4 population, particularly in regard to pain signaling (Snider and McMahon,

\footnotetext{
Received Nov. 2, 2001; revised Feb. 21, 2002; accepted March 1, 2002.

This work was supported by National Institutes of Health Grants NS31826 (B.M.D.) and NS/GM33730 (K.M.A.).We thank Dr. J. Springer (University of Kentucky) for providing the GDNF cDNA, Dr. C. Ibáñez (Karolinska Institute) for the Ret cDNA, Dr. R. Elde (University of Minnesota) for the P2X $\mathrm{X}_{3}$ antibody, and Dr. D. Julius (University of California San Francisco) for the VR1 antibody. We also thank Dr. B. Maley and M. G. Engle for assistance in electron and confocal microscopy, Teresa Noel for excellent technical assistance, and P. Crumrine for his statistical expertise (University of Kentucky).

Correspondence should be addressed to Kathryn M. Albers, Department of Medicine, Scaife Hall, Room 560A, University of Pittsburgh School of Medicine, Pittsburgh, PA 15261. E-mail: kaa2@pitt.edu.

Copyright (C) 2002 Society for Neuroscience $0270-6474 / 02 / 224057-09 \$ 15.00 / 0$
}

genic mice, few $(\sim 2 \%)$ IB4-positive neurons expressed the vanilloid receptor VR1, a heat-sensitive receptor expressed by many IB4-positive neurons of the rat. Thus, in mouse, GDNFdependent IB4-positive neurons must use a non-VR1 heat receptor. In addition, the behavior of GDNF-overexpresser animals to noxious heat or mechanical stimuli was indistinguishable from wild-type animals, indicating that, on a behavioral level, peripherally applied GDNF does not alter the sensitivity of the somatosensory system.

Key words: glial cell line-derived growth factor; transgenic mice; cutaneous; sensory neuron; somatosensory; development
1998). IB4-binding neurons form one of two groups of smalldiameter, unmyelinated C-fiber neurons (Silverman and Kruger, 1990; Kitchener et al., 1993). Many of these cells express the Ret receptor (Pachnis et al., 1993; Molliver et al., 1997; Bennett et al., 1998 ) and the purinergic receptor, $\mathrm{P}_{2} \mathrm{X}_{3}$ (Vulchanova et al., 1997), and project to lamina II of the spinal cord, suggesting a role in nociception (Snider and McMahon, 1998). In contrast, NGFdependent $\mathrm{C}$-fibers express the tyrosine kinase receptor A (trkA) and the peptides calcitonin gene-related peptide (CGRP) and substance P (Averill et al., 1995; Verge et al., 1995; Perl, 1996), and primarily project to lamina I-II (Woodbury et al., 2000).

The differences between GDNF- and NGF-dependent C-fibers suggest they represent nociceptors with distinct functional properties (Snider and McMahon, 1998). Conditions of chronic or persistent pain are accompanied by physiological, molecular, and anatomical changes in the sensory system, making it important to define how functional properties of IB4-negative and IB4positive neurons are established and regulated. Previous studies of transgenic mice that overexpress NGF (NGF-OE mice) showed that NGF caused significant changes in physiological properties of unmyelinated $\mathrm{C}$-fibers and myelinated $\mathrm{A} \delta$ fibers, both of which mediate pain (Davis et al., 1993; Stucky et al., 1999). These changes included increased sensitivity to mechanical and thermal stimuli, and in response properties, e.g., a fourfold increase in firing frequency in response to heat stimuli. Studies of IB4-positive neuron response properties, which are reported only for cultured neurons, show IB4-positive neurons have longerduration action potentials and smaller noxious heat-activated currents relative to non-IB4-binding neurons (Fjell et al., 1999; Stucky and Lewin, 1999).

In the present study, transgenic mice were used to examine how 
target overexpression of GDNF affects survival, differentiation, and properties of cutaneous neuron populations. This analysis shows that GDNF increases survival of a subclass of IB4-positive neurons and causes hypertrophy of IB4-positive afferents. Surprisingly, these changes did not elicit differences in behavioral response thresholds to either mechanical or heat stimuli. We also examined the effect of GDNF on expression of the heat-sensitive vanilloid receptor VR1 (Caterina et al., 2000). In rat, VR1 is expressed by 65-75\% of IB4-binding neurons (Guo et al., 1999; Michael and Priestley, 1999). In contrast, mouse DRG populations had a small (2-3\%) percentage of neurons that were both VR1 and IB4-positive. Overexpression of GDNF did not change this low percentage. Thus, a heat-sensitive channel other than VR1 must mediate heat sensitivity in IB4-positive neurons.

\section{MATERIALS AND METHODS}

Generation of transgenic mice. The K14-GDNF transgene contains $2.3 \mathrm{~kb}$ of the human K14 keratin promoter sequence, the mouse GDNF cDNA and intron-exon splice sites from the human growth hormone gene (Springer et al., 1995; Wang et al., 1997; LeMaster et al., 1999). After microinjection into $\mathrm{C} 3 \mathrm{H} \times \mathrm{B} 6 \mathrm{~F} 1$ embryos, four founder lines were isolated and used to produce F1 offspring. Mice were screened for the transgene using slot blot and PCR assays on DNA from tail skin. Reverse transcriptase-PCR analysis of RNA from back skin was used to assay relative level of transgene expression. Two lines (324 and 097) with highest expression levels were chosen for further study.

Reverse transcriptase-PCR. RNA was isolated from shaved back skin using Trizol (Invitrogen, Bethesda, MD). Samples were DNased, and 1 $\mu \mathrm{g}$ was reverse transcribed using Superscript (Invitrogen) and random primers in a $20 \mu \mathrm{l}$ reaction volume. cDNAs were PCR amplified in $50 \mu \mathrm{l}$ by adding $1.5 \mathrm{U}$ Taq polymerase (Promega, Madison, WI) PCR buffer, deoxyribonucleotide mix, primers specific to the transgene or endogenous GDNF (20 $\mu \mathrm{M}$ each), and $0.2 \mu \mathrm{l}$ of ${ }^{32} \mathrm{P}$-dCTP. A separate reaction to amplify actin was used as an internal standard. Typical reaction conditions were: $1 \mathrm{~min}: 94^{\circ} \mathrm{C}, 1 \mathrm{~min}: 60^{\circ} \mathrm{C}, 2 \mathrm{~min}: 72^{\circ} \mathrm{C}$. Band intensities were quantified using a Storm PhosphorImager and ImageQuant software (Molecular Dynamics, Sunnyvale, CA).

ELISA. Tissues were weighed and frozen until homogenized in sample buffer (0.1 M PBS, $0.4 \mathrm{M} \mathrm{NaCl}, 0.1 \%$ Triton X-100, $2 \mathrm{~mm}$ EDTA, $0.1 \mathrm{~mm}$ benzethonium chloride, $2 \mathrm{~mm}$ benzamidine, $0.1 \mathrm{~mm}$ PMSF, $20 \mathrm{~K} \mathrm{IU} / \mathrm{ml}$ aprotinin, and $0.5 \%$ BSA, $\mathrm{pH}$ 7.4) using either a polytron for skin or Duall type ground glass homogenizer for ganglia. Samples were spun at $13,000 \mathrm{rpm}$ for $15 \mathrm{~min}$ at $4^{\circ} \mathrm{C}$ and the supernatants were assayed using a GDNF ImmunoAssay kit (Promega).

Neuronal counting methodology. The number of neurons was determined using a modified Abercrombie counting method as described previously (Davis et al., 1996; Goodness et al., 1997). Briefly, ganglia were serial sectioned at $5 \mu \mathrm{m}$, stained using cresyl violet, and neurons containing visible nucleoli counted. Nucleolar number was summed and multiplied by the interval between counted sections.

In situ hybridization. In situ hybridization was done to detect Ret receptor mRNA using ${ }^{35} \mathrm{~S}$-labeled probes as described previously (Albers et al., 1994). Sense and antisense RNA riboprobes (262 nucleotides in length) were generated to sequences encoding the extracellular domain of the rat Ret receptor (Trupp et al., 1996). Ganglia were frozen on dry ice, cut into $15 \mu \mathrm{m}$ sections, and thaw mounted onto Superfrost slides. Sections were brought to room temperature, immersion-fixed for $15 \mathrm{~min}$ in $4 \%$ paraformaldehyde in PBS, and then washed in PBS, PBS with $0.2 \%$ glycine, and $0.25 \%$ acetic anhydride in $0.1 \mathrm{M}$ TEA, $\mathrm{pH}$ 8.0. Sections were dehydrated, air-dried, and incubated with probe hybridization solution (Amresco, Solon, $\mathrm{OH}$ ) containing $1 \times 10^{6} \mathrm{cpm} / 50 \mu \mathrm{l}$. A glass coverslip was placed over the probe and secured to the slide by applying mounting media around the cover glass. Slides were incubated overnight at $60^{\circ} \mathrm{C}$ and then dipped in NTB2 photographic emulsion, exposed 1-2 weeks, developed, and counterstained with hematoxylin and eosin. Sense transcript controls processed in parallel showed no specific hybridization.

Immunolabeling and histochemical analysis. Age-matched adult mice (4-6 months old) were deeply anesthetized with $2.5 \%$ avertin $(2,2,2$ tribromoethanol and tert-amyl alcohol diluted in $0.9 \%$ saline) and perfused transcardially with $4 \%$ paraformaldehyde in $0.1 \mathrm{M}$ phosphate buffer (PB). Dorsal root ganglia (L4/L5) were removed with a segment of spinal cord at the lumbar enlargement, immersed in $4 \%$ paraformaldehyde for 1 $\mathrm{hr}$, embedded in $10 \%$ gelatin in $0.1 \mathrm{M} \mathrm{PB}$, fixed for $1 \mathrm{hr}$, and then placed in $25 \%$ sucrose made in $0.1 \mathrm{M} \mathrm{PB}$ overnight at $4^{\circ} \mathrm{C}$. Sections were cut at $25 \mu \mathrm{m}$ using a sliding microtome, blocked $1 \mathrm{hr}$ at $25^{\circ} \mathrm{C}$ in $5 \%$ normal goat serum and $0.25 \%$ Triton $\mathrm{X}-100$, and incubated overnight in primary antibody. Primary antibodies used were made against the purinergic receptor, $\mathrm{P} 2 \mathrm{X}_{3}$ (1:1000), CGRP (1:4000; Chemicon, Temecula, CA), and the VR1 protein. Two anti-VR1 antibodies were used. In diaminobenzidine-horseradish peroxidase detection assays, a rabbit polyclonal antibody made to the C-terminal amino acids of the rat VR1 protein (Tominaga et al., 1998) was used at a 1:2000 dilution. For immunofluorescent labeling for confocal analysis, a rabbit antibody against the $\mathrm{N}$ terminus of rat VR1 was used (1:2000; Neuromics, Minneapolis, MN). Both VR1 antibodies produced similar labeling patterns in the DRG. For isolectin binding, the Bandeira simplicifolia isolectin (IB4, 1:100) was obtained from Sigma (St. Louis, MO). Antibody binding was visualized by avidin-biotin-peroxidase complex formation (Vector Laboratories, Burlingame, CA) or using fluorescent secondary binding (anti-rabbit IgG conjugated to Cy2 or Cy3; 1:200, Jackson ImmunoResearch Laboratories, Inc., West Grove, PA). For fluorescent detection, primary antibodies were used at the following dilutions: CGRP $(1: 1000), \mathrm{P}_{3},(1: 1000)$, VR1 (1:2000), and IB4-FITC (1:100). For colocalization studies, three sections from each ganglia were analyzed using a laser-scanning confocal microscope (Leica, Wetzlar, Germany) and the number of labeled cells for each marker was determined. Only those cells that contained nucleoli were counted. Area measurements of 150 labeled neurons in three sections from each animal were determined using Scion (Frederick, MD) Image software.

Saphenous nerve analysis. Mice were deeply anesthetized and perfused transcardially with $4 \%$ paraformaldehyde in $0.1 \mathrm{M}$ PB. Saphenous nerve segments at midthigh level were removed, post-fixed $2 \mathrm{hr}$ in $4 \%$ paraformaldehyde and $2 \%$ glutaraldehyde, washed in $0.2 \mathrm{M}$ Sorenson's phosphate buffer, immersed in osmium tetraoxide for $90 \mathrm{~min}$ at $4^{\circ} \mathrm{C}$, dehydrated in graded ethanols, embedded in Spurr's resin (EM Corporation, Chestnut Hills, MA), and cut at $0.7-0.8 \mathrm{~nm}$ on an ultramicrotome (Reichert Ultracut E). Sections were stained with lead citrate and uranyl acetate and photographed on an electron microscope (H7000; Hitachi Ltd., Tokyo, Japan), and the images were assembled into montages from which myelinated and unmyelinated axons were counted. To determine axon diameters, 300 axon profiles were measured in each group using Scion Image software.

Behavioral testing. Testing was performed without knowledge of genotype using age-matched wild-type $(n=10)$ and $\operatorname{GDNF}-\mathrm{OE}(n=10)$ mice. Mice were housed in group cages, maintained on a $12 \mathrm{hr}$ light/dark cycle in a temperature-controlled environment $\left(20.5^{\circ} \mathrm{C}\right)$, given food and water ad libitum, and tested at the same time of day. For hot plate measures, mice were confined to a Plexiglas cylinder $(19.0 \mathrm{~cm}$ diameter $\times$ $20.0 \mathrm{~cm}$ tall) on a hot plate set at $52.0 \pm 0.2^{\circ} \mathrm{C}$ (Columbus Instruments, Columbus, $\mathrm{OH}$ ). The time for a response (hindpaw shake/flutter or hindpaw lick) was measured to the nearest $0.1 \mathrm{sec}$. The test was performed twice a day for 3 consecutive days. For tail flick testing, mice were lightly restrained in a cloth and placed on a tail flick analgesia meter (Columbus Instruments) where a focused beam of light was applied directly to the middle of the tail until a response was elicited. Testing was performed twice a day for 3 consecutive days. Heat responsiveness was also measured using the Hargreaves' test (Hargreaves et al., 1988). Individual mice were placed in Plexiglas chambers $(10.0 \mathrm{~cm}$ length $\times 10.0 \mathrm{~cm}$ width $\times 13.0 \mathrm{~cm}$ height) set on a 6.0 -mm-thick glass surface (IITC Inc., Woodland Hills, CA.). Mice were acclimated to the chamber at least $2 \mathrm{hr}$ before testing. A radiant heat source (setting $=20$ ) was applied to the plantar surface of the mid-hindpaw of a resting mouse, and the tk;2withdraw latency was measured to the nearest $0.1 \mathrm{sec}$. The left hindpaw was tested on each mouse once a day for 3 consecutive days. Mechanical responsiveness was tested by applying von Frey filaments (Stoelting, Wood Dale, IL) of varying thickness to the dorsum of the foot and recording the force needed to elicit a response, e.g., hindpaw withdrawal, biting of the filament. Testing was done twice a day for 3 consecutive days.

Statistical analysis. Data are expressed as the mean \pm the SEM. Parametric and nonparametric statistical tests were performed as appropriate after fulfillment of all necessary prerequisites using the StatView software package (Abacus Concepts, Berkeley, CA).

\section{RESULTS}

\section{Isolation of GDNF-overexpressing transgenic mice}

The effect of target-derived GDNF on cutaneous sensory neurons was investigated using transgenic mice (GDNF-OE) that overex- 


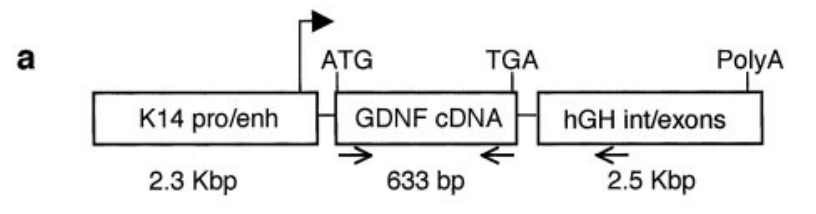

b

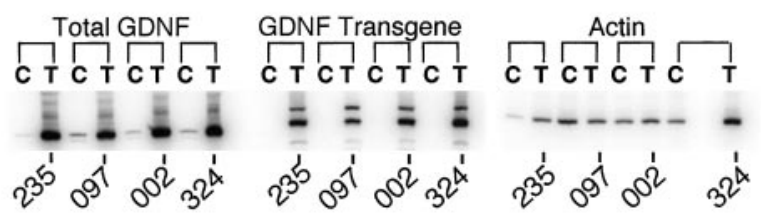

\begin{tabular}{l|cc} 
C Tissue type & Wildtype & GDNF-OE \\
\hline Dorsal skin (ng/g tissue) & $0.47 \pm 0.03$ & $2.93 \pm 0.53^{*}$ \\
DRG (ng/g tissue) & $5.14 \pm 0.42$ & $21.76 \pm 7.36$ * \\
Spinal cord (ng/g tissue) & $0.64 \pm 0.05$ & $1.71 \pm 0.15$ * \\
Serum (volume) & Not detected & Not detected
\end{tabular}

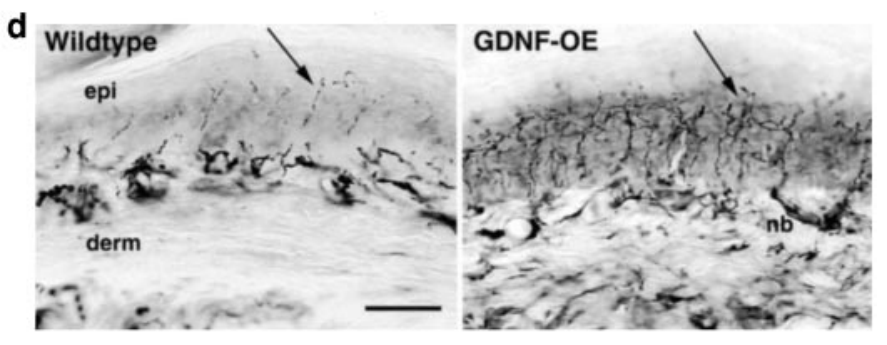

Figure 1. Characterization of GDNF-overexpressing transgenic mice. $a$, Gene construct for GDNF transgene expression. Large arrow indicates transcription start site; small arrows mark PCR primer binding sites used to detect endogenous and transgene GDNF mRNAs. b, Reverse transcriptase-PCR analysis shows relative level of GDNF mRNA in transgenic lines $(235,097,002$, and 324) relative to wild-type littermates. Shown are levels of total GDNF mRNA (endogenous and transgene derived), transgene-derived GDNF mRNA, and actin mRNA. $c$, ELISA measure of GDNF peptide in various tissues shows increased peptide in skin, ganglia, and spinal cord. $d$, Footpad skin immunolabeled with an antibody to PGP 9.5 shows skin of transgenic animals is hyperinnervated, particularly in lower epidermal layers (epi, epidermis; derm, dermis; $n b$, nerve bundle). Arrows indicate nerve fibers in epidermis. Scale bar, 50 $\mu \mathrm{m}$.

press GDNF in skin. Promoter elements of the K14 keratin gene were used to drive expression of the GDNF cDNA in skin keratinocytes (Fig. 1a). K14-regulated transcription begins in whiskerpad skin at approximately embryonic day 11 (E11) (Figueiredo et al., 2001), overlapping with expression of endogenous GDNF (Fundin et al., 1999). For dorsum and appendage skin, transgene expression is expected to occur later, after the cephalo-caudal gradient of endogenous K14 expression (approximately E13.5) (Byrne et al., 1994). Transgene expression continues into adulthood. Four founder lines $(002,097,235,324)$ were identified, and their offspring were screened using slot blots and PCR. Relative level of transgene transcription was defined in wild-type and GDNF-OE animals using semiquantitative RTPCR (Fig. 1b). Two lines (097 and 324) were established by mating F1 offspring to wild-type mice to produce heterozygous offspring. To verify transgene translation and specificity of trans-

\begin{tabular}{lll}
\hline \multicolumn{2}{l}{ Table 1. Cytochemical analysis of lumbar DRG neurons } \\
& $\begin{array}{l}\text { Wild type (\% of } \\
\text { total cells) }\end{array}$ & $\begin{array}{l}\text { GDNF-OE (\% of } \\
\text { total cells) }\end{array}$ \\
\hline Neuronal marker & $32.5 \pm 0.6$ & $48.9 \pm 2.3^{*}$ \\
CGRP & $29.9 \pm 3.2$ & $36.7 \pm 2.8$ \\
VR1 & $22.3 \pm 5.2$ & $15.4 \pm 0.7$ \\
P2X & $59.6 \pm 2.2$ & $57.2 \pm 0.8$
\end{tabular}

The percentage of IB4-, CGRP-, $\mathrm{P}_{2 \mathrm{X}_{3}-\text {, and VR1-positive neurons was determined }}$ by counting labeled and unlabeled cells containing visible nucleoli.

${ }^{*} p<0.050 ; t$ test. $n=3$ or 4 in each group. Data are expressed as mean $\pm \mathrm{SEM}$.

gene expression, ELISAs were done to measure peptide levels in the skin, DRG, spinal cord, and plasma of adult GDNF-OE and wild-type mice (Fig. 1c). A sixfold increase of GDNF protein was detected in transgenic skin, whereas in DRG, where retrograde transport from the skin is expected to increase GDNF peptide (Matheson et al., 1997; Leitner et al., 1999), a 4.23-fold increase was measured. Spinal cord levels were also increased by 2.67 -fold, suggesting anterograde transport of GDNF from the DRG to the dorsal horn. GDNF was not detected in the plasma of either wild-type or transgenic animals.

\section{Target expression of GDNF enhances the in vivo survival of specific sensory neuron types}

The increase in GDNF peptide in transgenic animals was accompanied by an increase in sensory neurons, as measured by counting neurons in cresyl violet-stained serial sections of the L4/L5 dorsal root ganglia. Counts showed a 27\% increase $(p<0.050 ; t$ test) in neuron number in adult GDNF-OE animals relative to wild-type littermates (wild-type, 16,831 \pm 2403; GDNF-OE, $21,399 \pm 999 ; n=3$ for each group). This increase indicates a rescue of DRG neurons from the normal development-associated program of cell death.

To identify the types of neurons rescued by GDNF overexpression, neurochemical and receptor properties of L4/L5 DRG neurons were analyzed. The percentage of neurons that express the Ret receptor was determined using in situ hybridization. In wildtype mice Ret-positive sensory neurons comprised $40.4 \%(n=3)$ of the DRG compared with $55.4 \%(n=3)$ in GDNF-OE ganglia, representing a $37 \%$ increase $(p<0.05)$. Ganglia were also labeled using IB4 and antibodies to CGRP, VR1, and the purinergic receptor $\mathrm{P}_{2} \mathrm{X}_{3}$ (Table 1). The GDNF-OE ganglia had 50\% more IB4-positive neurons (wild-type, 32.5\%; GDNF-OE, $48.9 \%$ ) (Fig. 2a,b), although no change was measured in the percentage of CGRP-positive neurons (Fig. $2 c, d$ ). In addition to number, the size of transgenic IB4-positive neurons was on average $50 \%$ greater than wild-type neurons (wild-type, 253.8 $\mathrm{mm}^{2} \pm$ 6.1; GDNF-OE, $516.4 \mathrm{~mm}^{2} \pm 37.8 ; p<0.01$ ) (Fig. 3a), compared with a $15 \%$ increase in diameter for CGRP-neurons (wild-type, $284.9 \mathrm{~mm}^{2} \pm 1.6$; GDNF-OE, $328.8 \mathrm{~mm}^{2} \pm 12.9 ; p<$ 0.05 ) (Fig. 3b). Thus, the primary effect of GDNF was on the nonpeptidergic IB4 population, although CGRP-positive neurons were also responsive.

We tested whether increased GDNF altered the percentage of neurons that express proteins involved in nociceptive processing by labeling sections of ganglia using antibodies against VR1 or the purinergic receptor $\mathrm{P} 2 \mathrm{X}_{3}$. VR1-positive neurons respond to noxious chemical (vanilloids) and heat stimuli (Caterina et al., 1997), whereas neurons expressing $\mathrm{P}_{2} \mathrm{X}_{3}$ respond to purinergic compounds associated with injury, e.g., ATP (Chen et al., 1995). No difference was measured in the percentage of VR1-neurons 


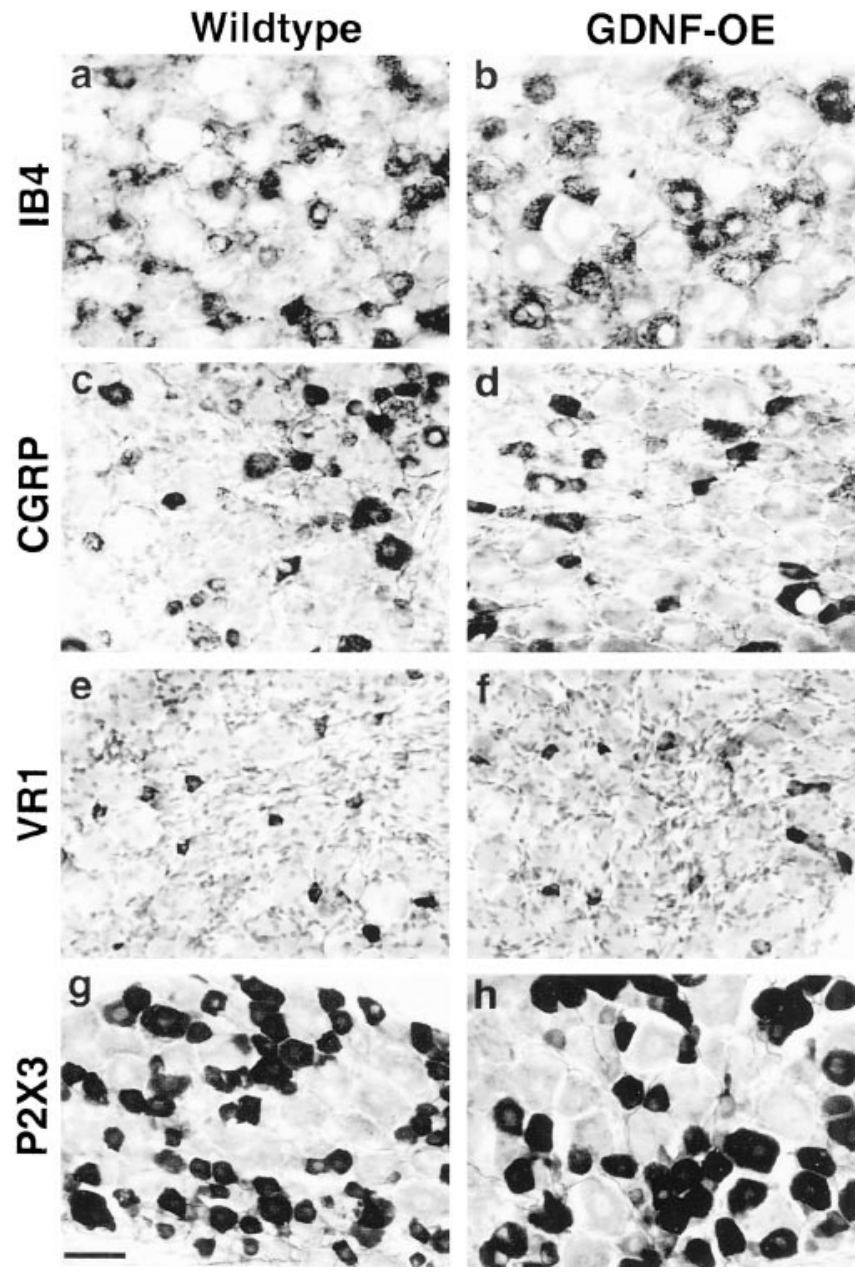

Figure 2. Cytochemical analysis of mouse L4/L5 dorsal root ganglia. $a$, $b$, Sections of DRG immunolabeled with an HRP-conjugated IB4 lectin. IB4-binding neurons of GDNF-OE mice are larger. Counts of labeled and unlabeled neurons showed their percentage also increased (Table 1). c, $d$, The CGRP-immunopositive population in GDNF-OE mice was slightly larger compared with wild-type ganglia. $e$, $f$, Immunolabeling using avidinbiotin HRP detection showed no change in the size or percentage of VR1-positive neurons in transgenic ganglia. $g, h$, The size and number of $\mathrm{P}_{2} \mathrm{X}_{3}$-positive neurons increased in GDNF-OE mice, although the percentage was unchanged. See also Table 1 . Scale bar, $50 \mu \mathrm{m}$.

between wild-type $(22.3 \%)$ and transgenic $(15.4 \%)$ ganglia (Table 1, Fig. $2 e, f)$, although a small increase $(16 \%)$ in the mean somal area occurred in transgenics (wild-type, $162.8 \mathrm{~mm}^{2} \pm 8.4$; GDNF-OE, $189.1 \mathrm{~mm}^{2} \pm 3.1 ; p<0.05$ ) (Fig. $3 d$ ). For $\mathrm{P}_{2} \mathrm{X}_{3^{-}}$ neurons, the percentage of $\mathrm{P} 2 \mathrm{X}_{3}$-positive profiles was unchanged in GDNF-OE ganglia (Table 1, Fig. $2 g, h$ ), but the average somal area increased dramatically and was $87 \%$ larger than wild-type measures (wild-type, $284.6 \mathrm{~mm}^{2} \pm 15.4$; GDNF-OE, $533.4 \mathrm{~mm}^{2} \pm$ 16.1; $p<0.0001$ ) (Fig. 3c).

Phenotypic overlap was analyzed by determining the amount of coexpression in IB4, CGRP, VR1, and $\mathrm{P}_{2} \mathrm{X}_{3}$ populations. Double-labeling of L4/L5 wild-type ganglia for IB4 and CGRP showed that only $3.5 \%$ of IB4-positive neurons expressed CGRP (Table 2, Fig. 4a,b), consistent with findings in the rat (Averill et al., 1995). This percentage was unchanged (3.8\%) in GDNF-OE ganglia. For $\mathrm{P}_{2} \mathrm{X}_{3}, 87 \%$ of wild-type and $81 \%$ of transgenic IB4-positive profiles were $\mathrm{P} 2 \mathrm{X}_{3}$-reactive, similar to studies in rat where $68 \%$ of IB4-positive cells were $\mathrm{P}_{2} \mathrm{X}_{3}$-positive (Bradbury et al., 1998). Although the number of IB4-positive neurons that express $\mathrm{P}_{2} \mathrm{X}_{3}$ was unchanged in transgenics, a slight increase in $\mathrm{P}_{2} \mathrm{X}_{3}$ neurons that express IB4 was measured (wild-type, 75\%; GDNF-OE, 88\%; $p<0.050$ ) (Table 2, Fig. 4e,f). For VR1 expression, an unexpectedly low percentage of overlap in VR1 and IB4 expression was found for both wild-type (2.83\%) and transgenic $(8.62 \%)$ ganglia (Table 2, Fig. $4 c, d)$. This was surprising in light of previous studies of rat DRG that showed $78 \%$ of VR1 neurons were IB4-positive (Guo et al., 1999) and indicates a significant difference between mouse and rat in VR1 expression.

\section{Cutaneous expression of GDNF modifies peripheral and central projections of sensory afferents}

Previous studies have shown that the phenotype and density of cutaneous sensory populations can be significantly modified by target overexpression of neurotrophic factors (Albers et al., 1994, 1996; LeMaster et al., 1999). To examine effects of GDNF on skin innervation, adult footpad skin was immunolabeled using an antibody to protein gene product 9.5 (PGP 9.5), a marker that labels both myelinated and unmyelinated fibers. Labeled fibers were increased in transgenic skin, particularly in the epidermis, where thin, beaded unbranched fibers infiltrated the basal and spinosum epidermal layers (Fig. 1d). These fibers were not tyrosine hydroxylase-positive, ruling out the possibility of their being sympathetic in origin (data not shown). In addition, no change was observed in the density or pattern of anti-CGRP labeling in the transgenic skin (data not shown). A significant increase in the density of $\mathrm{P}_{2} \mathrm{X}_{3}$ afferents was found in transgenic skin, particularly in the epidermis (data not shown). This increase likely reflects the increase in somal size measured in the $\mathrm{P}_{2} \mathrm{X}_{3^{-}}$positive neurons (Fig. 3c).

Afferents projecting to the transgenic skin were further examined by analysis of axons in the saphenous nerve, a cutaneous nerve that innervates skin of the medial calf and foot. The average cross-sectional profile of saphenous nerves in GDNF-OE mice was doubled in size relative to wild-type nerves (wild-type, 14,691 $\mathrm{mm}^{2} \pm 881$; GDNF-OE, 29,503 $\mathrm{mm}^{2} \pm 1555$ ) (Fig. 5a). This increase was reflected by a $59 \%$ increase in total axon number in GDNF-OE nerves (wild-type, $2290 \pm 147$; GDNFOE, $3633 \pm 81 ; p<0.05)$. The number of myelinated axons was increased $26 \%$ (wild-type, $543 \pm 28$; GDNF-OE, $687 \pm 12 ; p<$ 0.05 ), whereas unmyelinated axons increased $72 \%$ (wild-type, $1709 \pm 117$; GDNF-OE, $2945 \pm 74 ; p<0.05)$. To assess axon hypertrophy, the diameter of myelinated (without the myelin sheath) (Fig. 5b) and unmyelinated axons (Fig. 5d) was plotted as a frequency distribution histogram. On average, both myelinated and unmyelinated axons were hypertrophied in GDNF-OE mice, with the mean diameter for myelinated axons increased $39 \%$ (wild-type, $2.35 \mu \mathrm{m} \pm 0.06$; GDNF-OE $3.27 \mu \mathrm{m} \pm 0.19 ; p<$ 0.01 ), and unmyelinated diameters increased by $19 \%$ (wild-type, $0.59 \mu \mathrm{m} \pm 0.06$; GDNF-OE, $0.79 \mu \mathrm{m} \pm 0.02 ; p<0.05)$. The impact of axon hypertrophy on the thickness of the myelin sheath was also measured (Fig. 5c). Axon diameter was positively correlated with myelin thickness for both genotypes, although GDNF-OE axons had thinner myelin for a given axonal diameter. Thus, the increase in axon diameter in GDNF-OEs was not accompanied by a proportional increase in myelin thickness.

The central projections of IB4, CGRP, and VR1 populations were also evaluated by immunolabeling sections of lumbar spinal cord. IB4-positive projections in the dorsal horn were significantly enhanced (Fig. 6), whereas the band thickness of CGRPand VR1-positive afferents in lamina I were unchanged. 
a

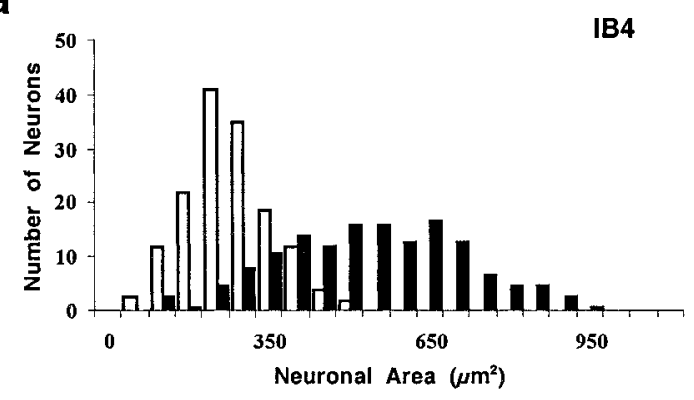

C

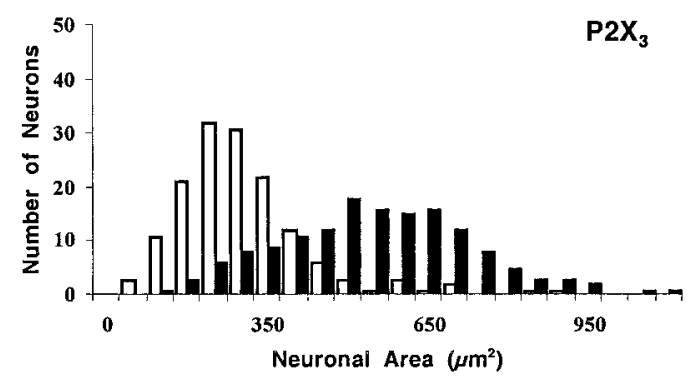

b

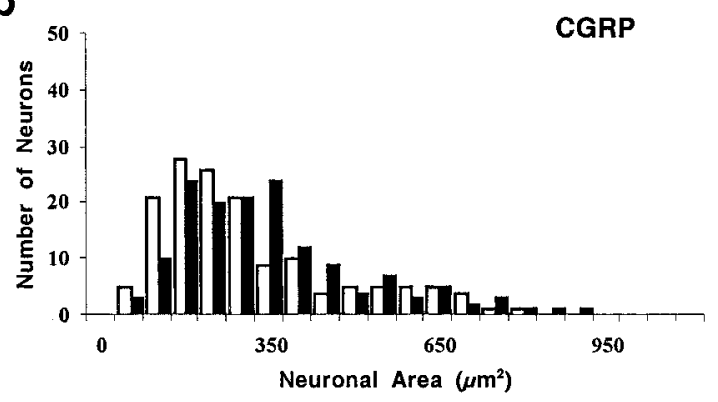

d

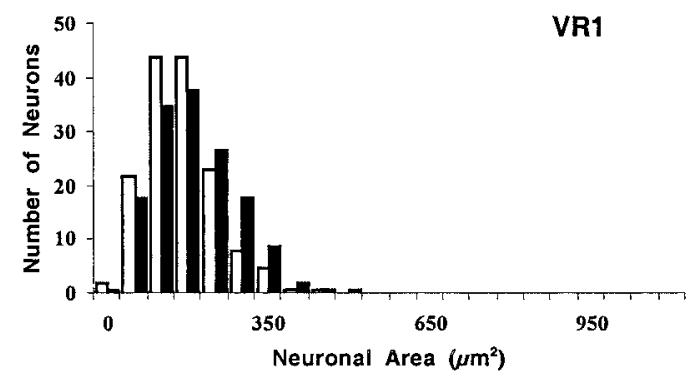

Figure 3. The effect of GDNF overexpression on the size distribution of specific neuronal populations. $a$, The distribution of neuronal areas for

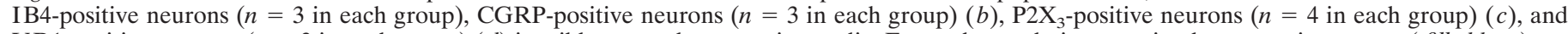
VR1-positive neurons ( $n=3$ in each group) $(d)$ in wild-type and transgenic ganglia. For each population examined, transgenic neurons ( filled bars) are significantly larger relative to wild-type neurons (open bars) $(p<0.050 ; t$ test).

Table 2. Colocalization of IB4 with CGRP, VR1, and P2X $\mathrm{X}_{3}$ in DRG neurons of wild-type and GDNF-OE mice

\begin{tabular}{|c|c|c|c|c|}
\hline \multirow[b]{2}{*}{ Marker } & \multicolumn{2}{|l|}{ Wild type } & \multicolumn{2}{|l|}{ GDNF-OE } \\
\hline & $\begin{array}{l}\% \text { IB4 neurons expressing } \\
\text { other marker }\end{array}$ & $\begin{array}{l}\% \text { of other marker } \\
\text { expressing IB } 4\end{array}$ & $\begin{array}{l}\% \text { IB4 neurons expressing } \\
\text { other marker }\end{array}$ & $\begin{array}{l}\% \text { of other marker } \\
\text { expressing IB4 }\end{array}$ \\
\hline CGRP & $3.53 \pm 0.76$ & $4.08 \pm 0.76$ & $3.79 \pm 1.32$ & $3.96 \pm 1.15$ \\
\hline VR1 & $1.98 \pm 0.80$ & $2.83 \pm 1.05$ & $3.10 \pm 0.18$ & $8.62 \pm 1.79^{*}$ \\
\hline $\mathrm{P} 2 \mathrm{X}_{3}$ & $87.31 \pm 2.03$ & $75.84 \pm 1.41$ & $81.77 \pm 4.90$ & $88.95 \pm 2.24 *$ \\
\hline
\end{tabular}

${ }^{*} p<0.050 ; t$ test. Data are expressed as mean \pm SEM.

GDNF-OE transgenic mice do not exhibit alterations in behavioral sensitivity to thermal and mechanical stimuli

GDNF-responsive, IB4-binding neurons are thought to comprise one of two populations of sensory neurons that mediate nociception. To test whether the increase in sensory neuron number and afferent projections affected the behavior of GDNF-OE animals to nociceptive stimuli, the response of animals to mechanical and heat stimuli were measured. Sensitivity to mechanical force was tested using calibrated von Frey filaments of varying thickness applied to the dorsum of the hindpaw until a response was elicited. No difference in response threshold was found between wild-type and GDNF-OE mice (Fig. 7). Three different behavioral tests for heat threshold were used to evaluate thermal sensitivity: (1) mice were placed on a hot plate set at $52^{\circ} \mathrm{C},(2)$ tails of mice were exposed to a focused radiant heat source, and (3) the ventral surface of the foot was exposed to a focused heat source (the Hargreaves' test). All three tests, performed on age-matched groups of animals, showed no difference in withdrawal response time between wild-type and GDNF-OE mice (Fig. 7). Thus, although significant changes occurred in the peripheral and central anatomy of GDNF-responsive populations, behavioral sensitivity to noxious stimuli was unchanged.

\section{DISCUSSION}

Increased expression of GDNF in the skin was found to enhance the survival and afferent projection density of a specific subset of DRG neurons. These findings demonstrate that GDNF, a member of the TGF- $\beta$ growth factor family, functions in vivo as a target-derived growth factor in a manner similar to the prototypical neurotrophin growth factor family. Given the $23 \%$ loss of neurons observed in P0 GDNF ${ }^{-1-}$ mice (Moore et al., 1996), the $27 \%$ increase in survival of L4/L5 DRG neurons caused by GDNF overexpression in the skin indicates that many of these GDNF-responsive DRG neurons are cutaneous afferents.

To determine the types of neurons affected by GDNF, we examined the physical and neurochemical properties of the DRG and spinal cord. GDNF overexpression increased the number and average size of myelinated and unmyelinated afferents, demonstrating heterogeneity in the phenotype of GDNF-responsive neurons. In wild-type mice, $40 \%$ of DRG neurons expressed mRNA encoding the kinase receptor Ret and $32 \%$ bound the lectin IB4. For GDNF-OE ganglia, the percentage of Ret neurons increased to $55 \%$, and IB4-positive neurons increased to $49 \%$ of the total population, representing a 37 and $50 \%$ increase, 

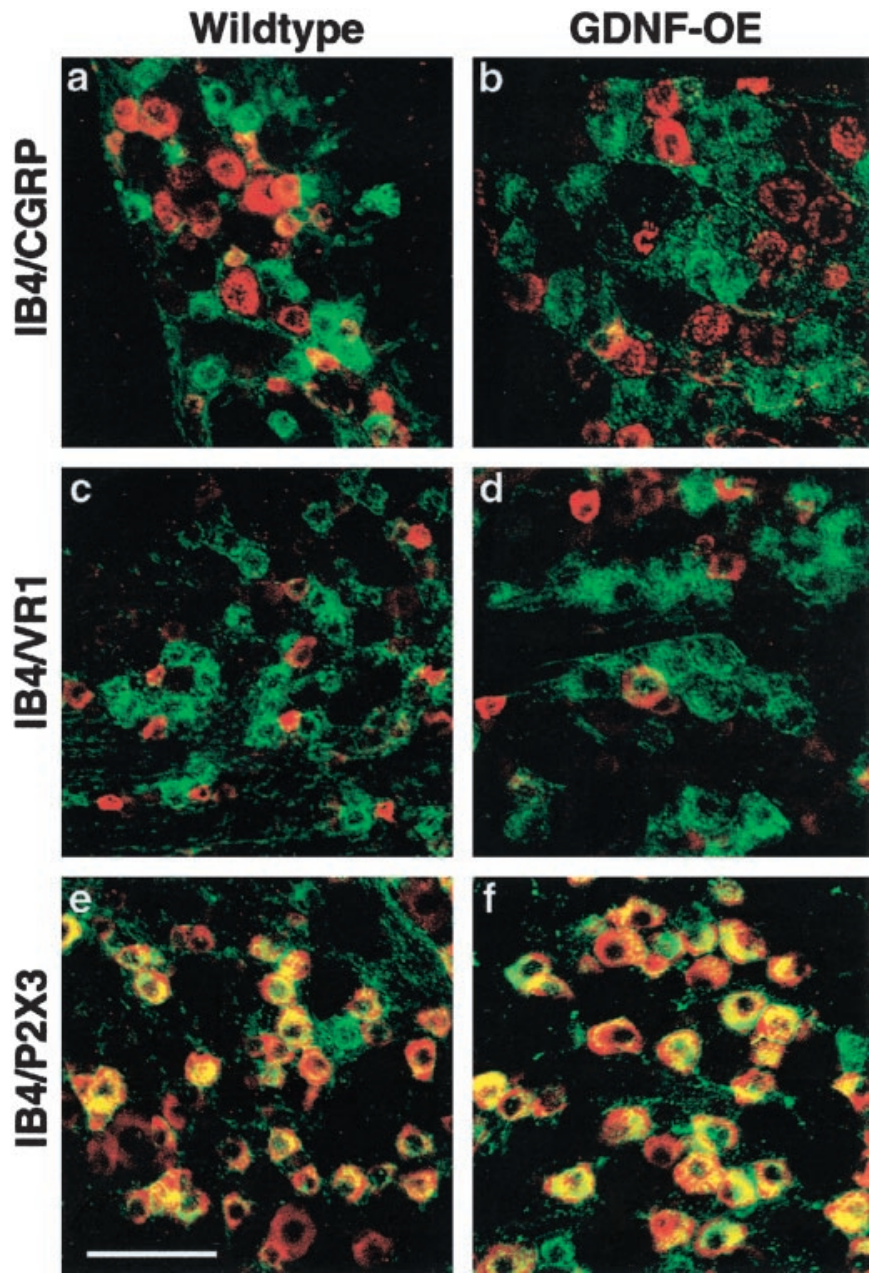

Figure 4. Analysis of phenotypic overlap in mouse dorsal root ganglia. $a$, $b$, Sections of DRG labeled with IB4 (green) and CGRP (red) show little overlap (yellow) between the two populations in wild-type and transgenic sections. $c, d$, Similar to IB4/CGRP overlap, IB4-positive (green) and VR1-positive (red) neurons have little overlap in wild-type and transgenic animals. $e, f$, Unlike VR1 and CGRP, IB4-positive (green) and $\mathrm{P}_{2} \mathrm{X}_{3^{-}}$ positive (red) neurons overlap almost completely. See also Table 2. Scale bar, $100 \mu \mathrm{m}$.

respectively. That a total rescue of Ret and IB4 populations did not occur likely reflects heterogeneity in trophic sensitivity, i.e., although most IB4-binding neurons express the Ret receptor (Molliver et al., 1997), some (12-20\%) express the NGF receptor trkA (Goodness et al., 1997). In addition, Ret-positive neurons express various GPI-linked GDNF family receptor- $\alpha$ coreceptors (GFR $\alpha$ s) that, in conjunction with Ret, bind other GDNF family ligands, e.g., neurturin, persephin, and artemin (Baloh et al., 1997, 1998; Klein et al., 1997; Milbrandt et al., 1998; Trupp et al., 1998). Thus, not all Ret and IB4-binding neurons are responsive to GDNF, i.e., express GFR $\alpha 1$. They may instead share or have exclusive responsiveness to NGF or other GDNF family members. This is demonstrated by a recent study that showed $30.5 \%$ of mouse DRG neurons that express GFR $\alpha 3$ are IB4-positive (Orozco et al., 2001). Because GFR $\alpha 3$ is the preferred coreceptor for artemin (Baloh et al., 1998), the GFR $\alpha 3$-positive IB4 neuron subset should be less affected (if at all) by GDNF overexpression. Similarly, DRG neurons that express the neurturin receptor GFR $\alpha 2$ should also be less affected by enhanced levels of GDNF. Phenotypic profiling of sensory populations in transgenic ani- mals further identified neuronal populations affected by GDNF expression. The percentage of CGRP neurons was unchanged in transgenic ganglia, as was the percentage of CGRP neurons that bound IB4. Although we expected the percentage of neurons that express CGRP and bind IB4 to be maintained, we did not expect the total population of CGRP neurons to be maintained because in rat, only $18 \%$ of trkA neurons (which are virtually all CGRPpositive) express the GFR- $\alpha 1$ coreceptor (Bennett et al., 1998). For the purinergic receptor $\mathrm{P}_{2} \mathrm{X}_{3}$, the percentage of labeled neurons was unchanged as well, although the subpopulation of $\mathrm{P} 2 \mathrm{X}_{3}$ neurons that were IB4-positive increased from 76 to $89 \%$ in transgenic ganglia. This increase was accompanied by a marked increase in somal size that likely reflects the increase in branching of $\mathrm{P} 2 \mathrm{X}_{3}$-positive fibers in the epidermis. The expression of the VR1 in transgenic ganglia was also examined. VR1 receptors bind capsaicin and are expressed in a subset of medium- and small-diameter primary afferents (Caterina et al., 1997). VR1 $1^{-/-}$ mice lack capsaicin sensitivity and are also impaired in the detection of noxious heat (Caterina et al., 2000), indicating a dual sensitivity. In rat, $67 \%$ of IB4-positive neurons expressed the VR1 receptor, suggesting VR1 imparts heat sensitivity to IB4binding neurons (Guo et al., 1999). Given the 50\% increase in IB4-binding neurons in GDNF-OE ganglia, it was surprising that the percentage of VR1 neurons in transgenics (15.4\%) was statistically unchanged relative to wild-type ganglia (22\%). Also unexpected was the low percentage of IB4-binding neurons in wild-type and transgenic ganglia that expressed VR1 (2-3\%). This low level of coexpression contrasts with the $67 \%$ coexpression in rat. The percentage of VR1-positive neurons that were IB4-positive in wild types was also quite low (2.8\%), but did increase in transgenic ganglia $(8.6 \%)$. This responsive population may reflect neurons that are CGRP-IB4-positive, because many CGRP neurons are VR1-positive (data not shown).

These findings present two possibilities with respect to the role of VR1 in heat sensitivity of mouse IB4-positive neurons: (1) mouse IB4-positive neurons are not sensitive to heat or (2) channels other than VR1 mediate heat sensitivity in these cells. The first possibility seems unlikely for several reasons. Studies on cultured mouse sensory neurons by Stucky and Lewin (1999) show that both IB4-positive and IB4-negative cells exhibit significant heat currents. These cell types differ in the size of their heat currents (heat currents of IB4-negative neurons are 70\% larger) and density of TTX-resistant channels (IB4-positive neurons have greater density), but the percentage of cells responding to heat in each population was the same (45\%). In addition, intracellular recordings by C. J. Woodbury and H. R. Koerber (unpublished data) of intact mouse sensory neurons show the majority of IB4-positive cells in wild-type mice exhibit brisk heat responses and that the percentage of responsive cells increases in GDNF-OE mice. The second possibility, that channels other than VR1 are responsible for heat sensitivity, is more likely and supported by studies of VR1 ${ }^{-1-}$ knock-out mice (Caterina et al., 2000). Although $\mathrm{VR} 1^{-/-}$mice exhibit a loss in the capsaicin response, recording from primary afferent fibers show a reduction, but not absence of a heat response. The heat response in $\mathrm{VR} 1^{-/-}$mice, like wild-type mice, exhibits a tight linear correlation between mean response rate and temperature, but the slope of this correlation is less in $\mathrm{VR} 1^{-1-}$ mice, indicating a reduced response. Thus, for IB4-positive neurons of the mouse, channels other than VR1 must transduce a heat response.

Given the heat sensitivity of IB4-binding neurons and the increase in neuron number and afferent projections in GDNF-OE 
a
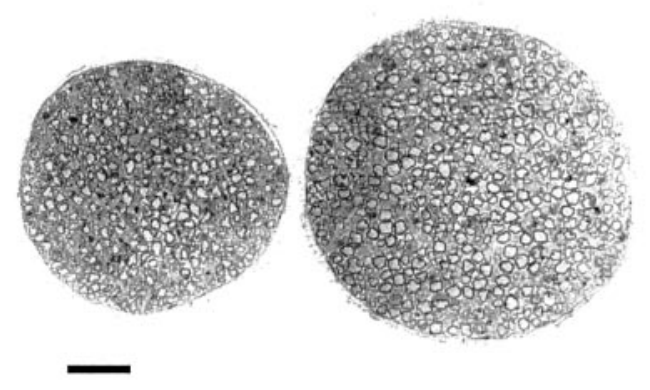

C

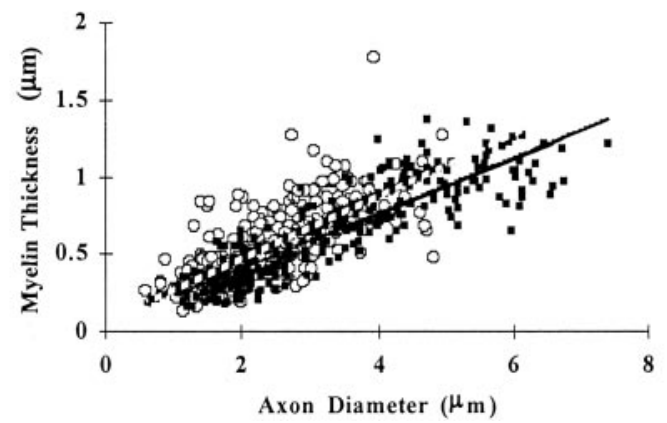

b

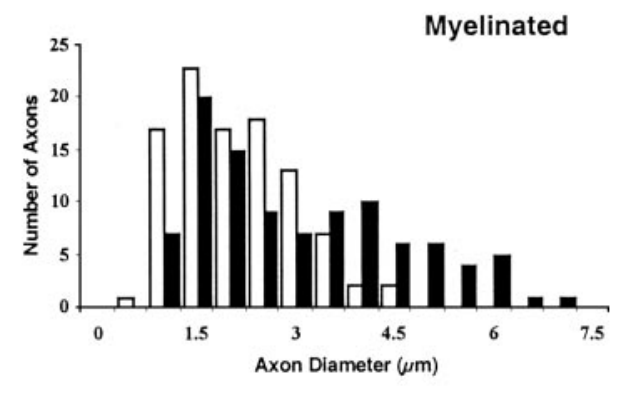

d

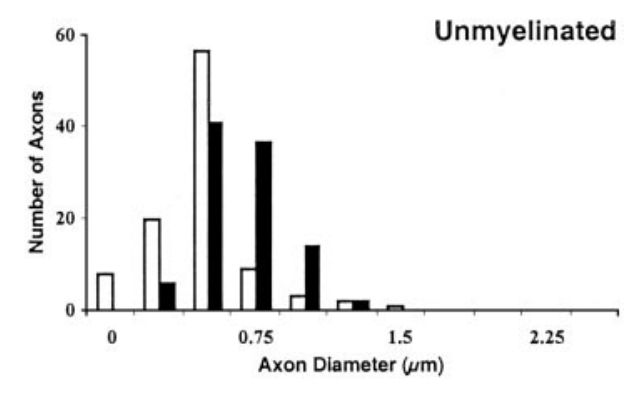

Figure 5. Overexpression of GDNF increases axon number and size in the saphenous nerve. $a$, Cross-section of representative sections from the saphenous nerve of GDNF-OE (left; $29,503 \pm 1555$ $\mathrm{mm}^{2}$ ) and age-matched wild-type mice (right; 14,691 $\pm 881 \mathrm{~mm}^{2}$ ). Nerve diameter was approximately double in transgenic mice. For each group, $n=3 ; p<$ $0.001 ; t$ test. Scale bar, $50 \mu \mathrm{m} . b, d$, Distribution of myelinated and unmyelinated axons in the saphenous nerve of wild-type (open bars) and GDNF-OE mice ( filled bars). For each group, $n=3$. Myelinated axon diameter includes the nerve axon only, without the myelin sheath. Note both axon distributions in GDNF-OE animals are shifted to the right, reflecting hypertrophy of myelinated and unmyelinated fibers $(p<0.050$; $t$-test). $c$, Regression analysis of myelin thickness versus axon diameter for wildtype (open circles, dashed line) and GDNF-OE mice (filled circles, continuous line). For each group, $n=3$. A significant linear correlation was calculated for both genotypes (wild-type, $r^{2}=0.53$; $p<0.001$; GDNF-OE, $r^{2}=0.79 ; p<$ 0.001 ), although GDNF-OE axons had thinner myelin for a given axonal diameter $(p<0.050$; ANCOVA).
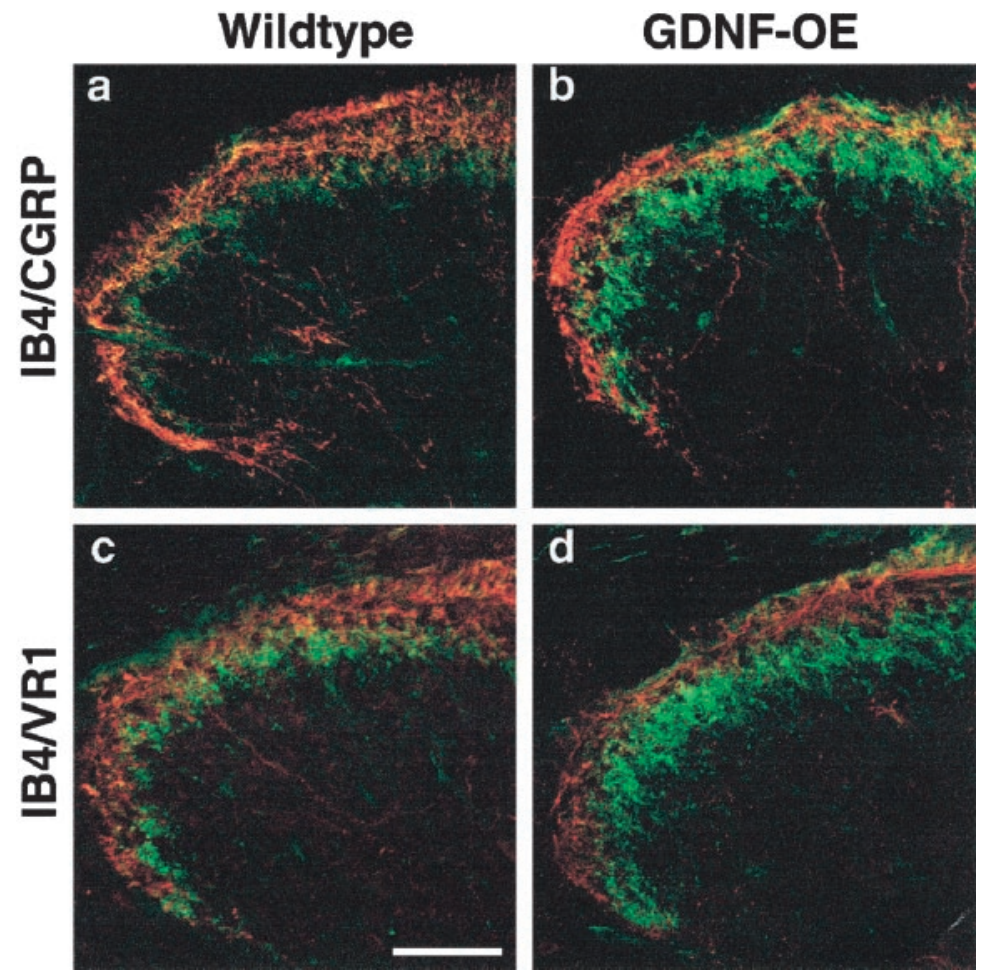

Figure 6. GDNF overexpression in skin increases primary afferent density in the spinal cord dorsal horn. $a, b$, The band of IB4 (green) labeling in the dorsal horn is broader and overlaps more superficially with the band of CGRP (red) labeling in GDNF-OE animals compared with wild-type animals. $c, d$, The band of VR1 (red) labeling shows no overlap with the band of IB4 (green) labeling and is unchanged in GDNF-OE mice. Scale bar, $100 \mu \mathrm{m}$.

mice, we tested age-matched animals using several behavioral paradigms with the expectation that these changes would elicit heightened sensitivity to noxious stimuli. Remarkably, sensitivity to heat and mechanical stimuli was unchanged in transgenics relative to wild-type animals. This finding differs significantly from animals that overexpress NGF in the skin (NGF-OEs), which have double the number of neurons that express trkA and CGRP and increased sensitivity on behavioral (Davis et al., 1993) and physi- ologic (Stucky et al., 1999) levels. Because both models exhibit hyperinnervation and increased cell numbers, what could underlie the difference between NGF and GDNF responses? One possibility is that the behavioral assays were not sufficiently sensitive to detect changes in GDNF-OE animals. This seems unlikely given the anatomical enhancements and the fact that three different approaches were used (for heat testing), all of which produced the same result. In addition, studies of primary afferent properties 
a

\begin{tabular}{l|cc} 
& $\begin{array}{c}\text { Wildtype } \\
\text { Latency (sec) }\end{array}$ & $\begin{array}{c}\text { GDNF-OE } \\
\text { Latency }(\mathrm{sec})\end{array}$ \\
\hline Hot plate & $17.54 \pm 1.68$ & $18.55 \pm 1.74$ \\
Tail flick & $1.15 \pm 0.04$ & $1.13 \pm 0.03$ \\
Foot withdrawal & $8.44 \pm 0.48$ & $9.54 \pm 1.05$
\end{tabular}

b

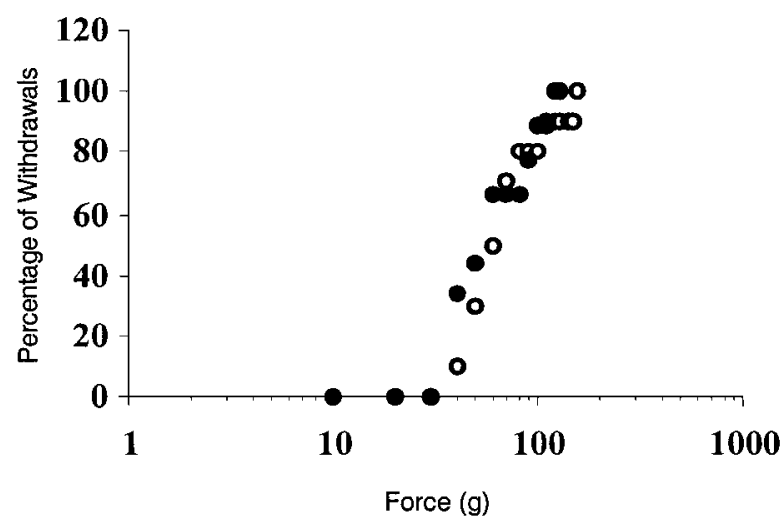

Figure 7. The GDNF-mediated enhancements of the sensory system do not affect thermal or mechanical behavioral sensitivity. $a$, Transgenic and wild-type animals were tested for changes in thermal sensitivity by exposing them to a hot plate set at $52.0 \pm 0.2^{\circ} \mathrm{C}$, a radiant heat source applied to the tail (tail flick), and radiant heat applied to the foot (Hargreaves' assay). No significant difference was measured between the behavior of transgenic and wild-type mice ( $n=10$ in each group). $b$, Cumulative sum distribution of mechanical thresholds to von Frey filament stimulation in wild-type (open circles) and GDNF-OE (filled circles) mice $(n=10$ in each group). No significant change in behavioral response was measured.

using an ex vivo preparation (Ritter et al., 2000) have shown that GDNF-OE mice have increased numbers of polymodal nociceptors that exhibit mechanical and heat sensitivity (Woodbury and Koerber, unpublished data). The lack of a behavioral phenotype in GDNF-OE mice could possibly result if the increased expression and transport of GDNF from the periphery to the spinal cord modifies the dorsal horn environment in a way that tempers input of noxious stimuli, e.g., by altering gene expression and/or the neurochemical environment. Enhanced transport of GDNF to the transgenic spinal cord is suggested based on the increase in GDNF peptide in transgenic spinal cord measured by ELISA. Additional support for such a mechanism is provided by immunolabeling studies of normal rat spinal cord that show GDNF immunoreactivity in the dorsal horn (Holstege et al., 1998) and the finding that GDNF, when applied intrathecally, is neuroprotective and reverses changes in behavior and gene expression elicited in models of neuropathic pain (Bennett et al., 1998; Bradbury et al., 1998; Boucher et al., 2000).

The protective and antinociceptive effects of GDNF and the lack of behavioral phenotype in GDNF-OE mice contrasts with the biologic effects associated with increased levels of NGF. For example, when intrathecally applied, NGF does not reverse the mechanical or thermal hypersensitivity that develops after a partial ligation of the sciatic nerve, whereas GDNF applied intrathecally does (Boucher et al., 2000). Mice that overexpress NGF in skin are also hypersensitive to mechanical and heat stimuli on single afferent and behavioral levels. Also unlike GDNF-OE mice, NGF-OE mice retain high levels of NGF in the ganglia and do not transport NGF to the spinal cord (Davis et al., 1994). Thus, both factors serve as target-derived survival factors for nociceptor development, but in adult systems their mode of action may diverge, with GDNF having direct central affects, whereas NGF affects peripheral tissues, e.g., regulating inflammatory cascades and gene expression in spinal ganglia. Having multiple nociceptor systems dependent on the balanced expression of several growth factors could impart an important homeostatic function that allows regulation and control of painful stimuli processing. Perturbations in this balance caused by injury or disease could underlie conditions in which abnormal pain signaling persists over extended periods of time.

\section{REFERENCES}

Albers KM, Wright DE, Davis BM (1994) Overexpression of nerve growth factor in epidermis of transgenic mice causes hypertrophy of the peripheral nervous system. J Neurosci 14:1422-1432.

Albers KM, Perrone TN, Goodness TP, Jones ME, Green MA, Davis BM (1996) Cutaneous overexpression of NT-3 increases sensory and sympathetic neuron number and enhances touch dome and hair follicle innervation. J Cell Biol 134:487-497.

Averill S, McMahon SB, Clary DO, Reichardt LF, Priestley JV (1995) Immunocytochemical localization of trkA receptors in chemically identified subgroups of adult rat sensory neurons. Eur J Neurosci 7:1484-1494.

Baloh RH, Tansey MG, Golden JP, Creedon DJ, Heuckeroth RO, Keck CL, Zimonjic DB, Popescu NC, Johnson EM Jr, Milbrandt J (1997) TrnR2, a novel receptor that mediates neurturin and GDNF signaling through Ret. Neuron 18:793-802.

Baloh RH, Tansey MG, Lampe PA, Fahrner TJ, Enomoto H, Simburger KS, Leitner ML, Araki T, Johnson EM Jr, Milbrandt J (1998) Artemin, a novel member of the GDNF ligand family, supports peripheral and central neurons and signals through the GFRalpha3-RET receptor complex. Neuron 21:1291-1302.

Bennett DL, Michael GJ, Ramachandran N, Munson JB, Averill S, Yan Q, McMahon SB, Priestley JV (1998) A distinct subgroup of small DRG cells express GDNF receptor components and GDNF is protective for these neurons after nerve injury. J Neurosci 18:3059-3072.

Boucher TJ, Okuse K, Bennett DL, Munson JB, Wood JN, McMahon SB (2000) Potent analgesic effects of GDNF in neuropathic pain states. Science 290:124-127.

Bradbury EJ, Burnstock G, McMahon SB (1998) The expression of P2X3 purinoreceptors in sensory neurons: effects of axotomy and glial-derived neurotrophic factor. Mol Cell Neurosci 12:256-268.

Byrne C, Tainsky M, Fuchs E (1994) Programming gene expression in developing epidermis. Development 120:2369-2383.

Caterina MJ, Schumacher MA, Tominaga M, Rosen TA, Levine JD, Julius D (1997) The capsaicin receptor: a heat-activated ion channel in the pain pathway. Nature 389:816-824.

Caterina MJ, Leffler A, Malmberg AB, Martin WJ, Trafton J, PetersenZeitz KR, Koltzenburg M, Basbaum AI, Julius D (2000) Impaired nociception and pain sensation in mice lacking the capsaicin receptor. Science 288:306-313.

Chen CC, Akopian AN, Sivilotti L, Colquhoun D, Burnstock G, Wood JN (1995) A P2X purinoceptor expressed by a subset of sensory neurons. Nature 377:428-431.

Davis BM, Lewin GR, Mendell LM, Jones ME, Albers KM (1993) Altered expression of nerve growth factor in the skin of transgenic mice leads to changes in response to mechanical stimuli. Neuroscience 56:789-792.

Davis BM, Albers KM, Seroogy KB, Katz DM (1994) Overexpression of nerve growth factor in transgenic mice induces novel sympathetic projections to primary sensory neurons. J Comp Neurol 349:464-474.

Davis BM, Wang HS, Albers KM, Carlson SL, Goodness TP, McKinnon D (1996) Effects of NGF overexpression on anatomical and physiological properties of sympathetic postganglionic neurons. Brain Res 724:47-54.

Figueiredo HF, Davis BM, Albers KM (2001) Skin-derived nerve growth factor blocks programmed cell death in the trigeminal ganglia but does not enhance neuron proliferation. Mech Dev 109:205-214.

Fjell J, Cummins TR, Fried K, Black JA, Waxman SG (1999) In vivo NGF deprivation reduces SNS expression and TTX-R sodium currents in IB4-negative DRG neurons. J Neurophysiol 81:803-810.

Fundin BT, Mikaels A, Westphal H, Ernfors P (1999) A rapid and dynamic regulation of GDNF-family ligands and receptors correlate with the developmental dependency of cutaneous sensory innervation. Development 126:2597-2610.

Goodness TP, Albers KM, Davis FE, Davis BM (1997) Overexpression 
of nerve growth factor in skin increases sensory neuron size and modulates Trk receptor expression. Eur J Neurosci 9:1574-1585.

Guo A, Vulchanova L, Wang J, Li X, Elde R (1999) Immunocytochemical localization of the vanilloid receptor 1 (VR1): relationship to neuropeptides, the P2X3 purinoceptor and IB4 binding sites. Eur J Neurosci 11:946-958.

Hargreaves K, Dubner R, Brown F, Flores C, Joris J (1988) A new and sensitive method for measuring thermal nociception in cutaneous hyperalgesia. Pain 32:77-88.

Holstege JC, Jongen JL, Kennis JH, van Rooyen-Boot AA, Vecht CJ (1998) Immunocytochemical localization of GDNF in primary afferents of the lumbar dorsal horn. NeuroReport 9:2893-2897.

Kitchener PD, Wilson P, Snow PJ (1993) Selective labelling of primary sensory afferent terminals in lamina II of the dorsal horn by injection of Bandeiraea simplicifolia isolectin B4 into peripheral nerves. Neuroscience 54:545-551.

Klein RD, Sherman D, Ho WH, Stone D, Bennett GL, Moffat B, Vandlen R, Simmons L, Gu Q, Hongo JA, Devaux B, Poulsen K, Armanini M, Nozaki C, Asai N, Goddard A, Phillips H, Henderson CE, Takahashi M, Rosenthal A. (1997) A GPI-linked protein that interacts with Ret to form a candidate neurturin receptor. Nature 387:717-721.

Leitner ML, Molliver DC, Osborne PA, Vejsada R, Golden JP, Lampe PA, Kato AC, Milbrandt J, Johnson EM Jr (1999) Analysis of the retrograde transport of glial cell line-derived neurotrophic factor (GDNF), neurturin, and persephin suggests that in vivo signaling for the GDNF family is GFRalpha coreceptor-specific. J Neurosci 19:9322-9331.

LeMaster AM, Krimm RF, Davis BM, Noel T, Forbes ME, Johnson JE, Albers KM (1999) Overexpression of brain-derived neurotrophic factor enhances sensory innervation and selectively increases neuron number. J Neurosci 19:5919-5931.

Lin LF, Doherty DH, Lile JD, Bektesh S, Collins F (1993) GDNF: a glial cell line-derived neurotrophic factor for midbrain dopaminergic neurons. Science 260:1130-1132.

Matheson CR, Carnahan J, Urich JL, Bocangel D, Zhang TJ, Yan Q (1997) Glial cell line-derived neurotrophic factor (GDNF) is a neurotrophic factor for sensory neurons: comparison with the effects of the neurotrophins. J Neurobiol 32:22-32.

Michael GJ, Priestley JV (1999) Differential expression of the mRNA for the vanilloid receptor subtype 1 in cells of the adult rat dorsal root and nodose ganglia and its downregulation by axotomy. J Neurosci 19:1844-1854.

Milbrandt J, de Sauvage FJ, Fahrner TJ, Baloh RH, Leitner ML, Tansey MG, Lampe PA, Heuckeroth RO, Kotzbauer PT, Simburger KS, Golden JP, Davies JA, Vejsada R, Kato AC, Hynes M, Sherman D, Nishimura M, Wang LC, Vandlen R, Moffat B, et al. (1998) Persephin, a novel neurotrophic factor related to GDNF and neurturin. Neuron 20:245-253.

Molliver DC, Wright DE, Leitner ML, Parsadanian AS, Doster K, Wen D, Yan Q, Snider WD (1997) IB4-binding DRG neurons switch from NGF to GDNF dependence in early postnatal life. Neuron 19:849-861.

Moore MW, Klein RD, Farinas I, Sauer H, Armanini M, Phillips H, Reichardt LF, Ryan AM, Carver-Moore K, Rosenthal A (1996) Renal and neuronal abnormalities in mice lacking GDNF. Nature 382:76-79.

Oppenheim RW (1991) Cell death during development of the nervous system. Annu Rev Neurosci 14:453-501.

Orozco OE, Walus L, Sah DW, Pepinsky RB, Sanicola M (2001) GFR- alpha3 is expressed predominantly in nociceptive sensory neurons. Eur J Neurosci 13:2177-2182.

Pachnis V, Mankoo B, Constantini F (1993) Expression of the c-ret protooncogene during mouse embryogenesis. Development 119:1005-1017.

Perl ER (1996) Cutaneous polymodal receptors: characteristics and plasticity. Prog Brain Res 113:21-37.

Ritter AM, Woodbury CJ, Albers K, Davis BM, Koerber HR (2000) Maturation of cutaneous sensory neurons from normal and NGFoverexpressing mice. J Neurophysiol 83:1722-1732.

Silverman JD, Kruger L (1990) Selective neuronal glycoconjugate expression in sensory and autonomic ganglia: relation of lectin reactivity to peptide and enzyme markers. J Neurocytol 19:789-801.

Snider WD (1994) Functions of the neurotrophins during nervous system development: what the knockouts are teaching us. Cell 77:627-638.

Snider WD, McMahon SB (1998) Tackling pain at the source: new ideas about nociceptors. Neuron 20:629-632.

Springer JE, Seeburger JL, He J, Gabrea A, Blankenhorn EP, Bergman LW (1995) cDNA sequence and differential mRNA regulation of two forms of glial cell line-derived neurotrophic factor in Schwann cells and rat skeletal muscle. Exp Neurol 131:47-52.

Stucky CL, Lewin GR (1999) Isolectin B(4)-positive and -negative nociceptors are functionally distinct. J Neurosci 19:6497-6505.

Stucky CL, Koltzenburg M, Schneider M, Engle MG, Albers KM, Davis BM (1999) Overexpression of nerve growth factor in skin selectively affects the survival and functional properties of nociceptors. J Neurosci 19:8509-8516.

Thoenen H, Barde YA, Davies AM, Johnson JE (1987) Neurotrophic factors and neuronal death. Ciba Found Symp 126:82-95.

Tominaga M, Caterina MJ, Malmberg AB, Rosen TA, Gilbert H, Skinner K, Raumann BE, Basbaum AI, Julius D (1998) The cloned capsaicin receptor integrates multiple pain-producing stimuli. Neuron 21:531-543.

Trupp M, Ryden M, Jornvall H, Funakoshi H, Timmusk T, Arenas E, Ibanez CF (1995) Peripheral expression and biological activities of GDNF, a new neurotrophic factor for avian and mammalian peripheral neurons. J Cell Biol 130:137-148.

Trupp M, Arenas E, Fainzilber M, Nilsson AS, Sieber BA, Grigoriou M, Kilkenny C, Salazar-Grueso E, Pachnis V, Arumae U (1996) Functional receptor for GDNF encoded by the c-ret proto-oncogene. Nature 381:785-789.

Trupp M, Raynoschek C, Belluardo N, Ibanez CF (1998) Multiple GPIanchored receptors control GDNF-dependent and independent activation of the c-Ret receptor tyrosine kinase. Mol Cell Neurosci 11:47-63.

Verge VM, Richardson PM, Wiesenfeld-Hallin Z, Hokfelt T (1995) Differential influence of nerve growth factor on neuropeptide expression in vivo: a novel role in peptide suppression in adult sensory neurons. J Neurosci 15:2081-2096.

Vulchanova L, Riedl MS, Shuster SJ, Buell G, Surprenant A, North RA, Elde R (1997) Immunohistochemical study of the P2X2 and P2X3 receptor subunits in rat and monkey sensory neurons and their central terminals. Neuropharmacology 36:1229-1242.

Wang X, Zinkel S, Polonsky K, Fuchs E (1997) Transgenic studies with a keratin promoter-driven growth hormone transgene: prospects for gene therapy. Proc Natl Acad Sci USA 94:219-226.

Woodbury CJ, Ritter AM, Koerber HR (2000) On the problem of lamination in the superficial dorsal horn of mammals: a reappraisal of the substantia gelatinosa in postnatal life. J Comp Neurol 417: $88-102$. 